Available online at: https://researchsynergy.org/ijmesh/

International Journal of Management, Entrepreneurship, Social Science and Humanities

(IJMESH)

ISSN 2580-0981 (online)

Volume 4 Number 2 (2021): 11-27

\title{
The Role of Job Satisfaction in Mediating the Effect of Competency and Perceived Organizational Support on Education Performance: An Evidence from the Muhammadiyah University of Jember, Indonesia
}

\author{
Septy Holisa Umamy \\ University of Jember, Indonesia
}

\begin{abstract}
Abstract: Educational staff in universities have an important role in supporting performance, so it is necessary to know the factors that affect performance. Efforts to improve performance by understanding organizational behavior. Organizational behavior will affect work behavior, including competence, perceived organizational support, and job satisfaction. The population in this study was 120 education personnel at the Muhammadiyah University of Jember. The sampling method of this study was a saturated sample, so that the number of samples was 120 education personnel. Sampling process using google forms. Data analysis using Partial Least Square (PLS) method with SmartPLS software. The results in this study are all accepted hypotheses, both direct and indirect effects. Competency variables directly affect performance and job satisfaction; Perceived organization support has a direct effect on performance and job satisfaction. Job satisfaction has a direct influence on performance; job satisfaction acts as a mediating variable on the effect of competence on performance and the effect of perceived organizational support on performance. Suggestions in this study to improve competence need to provide training and provide career development to education staff. The results of the study are supported by research by Susanto (2018), Agustyna \& Prasetyo (2020), Fitri, Marnis, and Garnasih (2020), which state that competence, perceived organizational support, and job satisfaction have an effect on employee performance.
\end{abstract}

Keywords: Organizational Behavior; Performance; Education Personnel

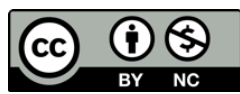

This is an open access article under the CC-BY-NC license.

\section{INTRODUCTION}

Higher education institutions in which there are various kinds of resources must not be allowed to run without directed management and management and are required to continue to move towards achieving the best higher education quality, and the resources they have must be measured and distributed properly. One aspect of the governance of the education system is teaching staff and education. Educational personnel is the most important part to measure the success of the implementation of educational administration activities, where their existence occupies a strategic position and role in the governance of the process of organizing the Tridarma of higher education. This shows that educational staff in carrying out their duties administratively and servicing higher education institutions are required to be able to work in a more professional and measured direction. Measuring the performance of education personnel is one of the processes used for evaluation activities by the management level of activities that have been carried out by educational personnel against the targets set by the college; the appropriate performance measure will create optimal higher education performance. Efforts to increase the optimal performance of higher education need to understand organizational behavior. Individual behavior is formed by three factors, namely competence or skills, perceptions, and attitudes that will affect performance 
International Journal of Management, Entrepreneurship, Social Science and Humanities (IJMESH), Vol. 4 (2), 11-27 The Role of Job Satisfaction in Mediating the Effect of Competency and Perceived Organizational Support on Education Performance

Septy Holisa Umamy

(Ivancevich et al., 2007). Competence affects performance stated by Gilley, Boughton, and Maycunich (in Fitri, 2020). This is in line with research conducted by Syarif (2020), Girniawan, Perizade et al. (2019). In addition to influencing the performance of competencies, it also has an influence on increasing job satisfaction of educational personnel. Competence will help education staff to achieve their own job satisfaction. The results of research conducted by Ramadhan, Pongtuluran and Wahyuni (2020), Fitri, Marnis and Garnasih (2020). In addition to competencies, individual characteristics that affect performance are perceptions of organizational support. In addition to influencing the performance of competencies, it also has an influence on increasing job satisfaction of educational personnel. Competence will help education staff to achieve their own job satisfaction. The results of research conducted by Ramadhan, Pongtuluran and Wahyuni (2020), Fitri, Marnis and Garnasih (2020). In addition to competencies, individual characteristics that affect performance are perceptions of organizational support. In addition to influencing the performance of competencies, it also has an influence on increasing job satisfaction of educational personnel. Competence will help education staff to achieve their own job satisfaction. The results of research conducted by Ramadhan, Pongtuluran and Wahyuni (2020), Fitri, Marnis and Garnasih (2020). In addition to competencies, individual characteristics that affect performance are perceptions of organizational support.

Perceived organizational support is the degree to which employees believe the organization values their contributions and cares about their welfare (Tewal et al., 2017: 94). The high Perceived organizational support that is felt by education personnel will increase job satisfaction in educational personnel. Job satisfaction is the feeling of a person about his work that is produced by his own business and which is supported by things that are external to himself on the condition of work, the results of work, and the work itself (Sinambela, 2016: 303).

Referring to previous research, which was considered relevant, but on the other hand, a research gap was found by Aima, Adam, and Ali (2017), which showed that there was no influence between job competence on employee performance. In addition, there is research that shows the inconsistency of the results that the Perceived organizational support does not have a significant effect on employee performance. Yulivianto (2019), Agustiningrum (2016), where the level of perceived organizational support is not able to affect the performance of education personnel. Research conducted by Warsi et al. (2020) shows that job satisfaction does not have a significant effect on employee performance; when education personnel have high job satisfaction, it will not necessarily improve their performance.

The Muhammadiyah University of Jember has implemented ISO 21002: 2018 regarding the management system of educational organizations, which in its interpretation is an evaluation of the performance of educators and educational staff. The performance evaluation applied refers to the points of staffing at the University of Muhammadiyah Jember number: 035 / II.3.AU / BPH / I / 2014 regarding employee appraisals and documents of the Quality Assurance Agency (LPM) regarding the performance appraisal of education personnel. Dok: FM- 00007 20011-02. The focus in this study is educational staff because based on the results of the evaluation; there were several performance problems, including $45 \%$ of education personnel arriving late, $23.5 \%$ disciplined in doing fingerprint attendance, and $76.5 \%$ not yet disciplined to do fingerprints (data from the 
Muhammadiyah University Personnel Bureau. Jember, 2020). In addition, there are several complaints from students and lecturers regarding the less-than-optimal service for teaching staff. The not optimal performance of the educational staff at the University of Muhammadiyah Jember is caused by several factors, including competence, perceived organizational support, and job satisfaction, wherein, in this case, several gaps are still found.

\section{LITERATURE REVIEW}

\begin{tabular}{|c|c|c|c|c|c|}
\hline No & Name, Year and Title of Research & Research variable & Population and Sample & $\begin{array}{c}\text { Analysis } \\
\text { Techniques }\end{array}$ & Research result \\
\hline 1. & $\begin{array}{l}\text { Susanto (2018) the title "The Influence } \\
\text { of Work Environment and Individual } \\
\text { Competence on Employee } \\
\text { Performance at PT. North Sumatra } \\
\text { Plantation" }\end{array}$ & $\begin{array}{l}\text { 1. Work } \\
\text { environment } \\
\text { 2. Individual } \\
\text { Competence } \\
\text { 3. Performance }\end{array}$ & $\begin{array}{lll}\text { Population } & 157 & \text { and } \\
\text { Sample } 43 & & \end{array}$ & $\begin{array}{l}\text { Multiple } \\
\text { Regression } \\
\text { Analysis }\end{array}$ & $\begin{array}{l}\text { Work environment and individı } \\
\text { competence have a positive a! } \\
\text { significant effect simultaneous } \\
\text { and partially on employ } \\
\text { performance at PT. North Sumat } \\
\text { Plantation }\end{array}$ \\
\hline 8. & $\begin{array}{l}\text { Agustyna \& Prasetyo (2020), the title } \\
\text { "The Influence of Perception of } \\
\text { Organizational Support and Job } \\
\text { Satisfaction on Employee Performance } \\
\text { at PT Great Citra Lestari" }\end{array}$ & $\begin{array}{ll}\text { 1. } & \text { Organizational } \\
& \text { Support } \\
& \text { Perception } \\
\text { 2. } & \text { Job satisfaction } \\
\text { 3. } & \text { Performance }\end{array}$ & Population and Sample 44 & $\begin{array}{l}\text { Path Analysis } \\
\text { With SPSS Toolkit }\end{array}$ & $\begin{array}{ll}\text { 1. } & \text { Perception } \\
& \text { organizational suppc } \\
& \text { has a significant effect } \\
& \text { job satisfaction, } \\
\text { 2. } & \text { Perception } \\
& \text { organizational suppc } \\
& \text { has a significant effect } \\
& \text { employee performance, }\end{array}$ \\
\hline 11. & $\begin{array}{l}\text { Deswarta (2017) with the title "The } \\
\text { Influence of Competence and } \\
\text { Motivation on Job Satisfaction and } \\
\text { Performance of Lecturers of the } \\
\text { Tarbiyah and Teacher Training } \\
\text { Faculty of UIN Sultan Syarif Kasim } \\
\text { Riau" }\end{array}$ & $\begin{array}{l}\text { 1. } \text { Competence } \\
\text { 2. Motivation } \\
\text { 3. Job satisfaction } \\
\text { 4. Performance }\end{array}$ & $\begin{array}{ll}\text { Population } & 191 \\
\text { Sample } 129 & \end{array}$ & $\begin{array}{l}\text { Multiple Linear } \\
\text { Regression with } \\
\text { SPSS 17. Tool }\end{array}$ & $\begin{array}{l}\text { 1. Competence al } \\
\text { motivation are very go } \\
\text { both have a partial effe } \\
\text { on job satisfacti } \\
\text { kepuasan }\end{array}$ \\
\hline
\end{tabular}

\section{Figure 1 Previous Research}

Based on previous research regarding the equation of variables on competence, perceived organizational support, job satisfaction, and performance on employees, however, there are still some shortcomings that need to be re-examined, especially in education staff, where this study will discuss organizational behavior that will work behavior using PLS Techniques SEM.

Organizational Behavior Theory

According to Wijaya (2017: 1) suggests that organizational behavior is a discipline that studies individual behavior in organizations and their impact on performance, both individual, group, and organizational performance. 
International Journal of Management, Entrepreneurship, Social Science and Humanities (IJMESH), Vol. 4 (2), 11-27

The Role of Job Satisfaction in Mediating the Effect of Competency and Perceived Organizational Support on Education Performance

Septy Holisa Umamy

Competency

Competence is a characteristic that underlies the nature of an individual, which is causal or performance related to superior traits in certain jobs or situations Tagala (2018: 153).

Perceptions of Organizational Support

Perceived organizational support is the degree to which employees believe the organization appreciates their contribution and cares about their welfare Tewal et al., (2017: 94).

Job satisfaction

Job satisfaction is a person's feeling of work that is produced by his own business and which is supported by things from outside himself regarding the working conditions, the results of work, and the work itself (Sinambela, 2016: 303).

Performance

According to Afandi (2018: 83), performance is the result of work that can be achieved by a person or group of people in a company in accordance with their respective authorities and responsibilities in an effort to achieve organizational goals legally, does not violate the law and does not conflict with morals and ethics.

Hypothesis

To develop our goals, we want to test the following hypotheses:

Ha1 : Competencies Influence the Performance of Educational Personnel at the University of Muhammadiyah Jember

Ha2 : Perceived organizational support Influence the Performance of Educational Personnel at the University of Muhammadiyah Jember

Ha3 : Competencies Influence Job Satisfaction of Educational Personnel, University of Muhammadiyah Jember

Ha4 : Perceived organizational support Influence the Job Satisfaction of Educational Personnel, University of Muhammadiyah Jember

Ha5 : Job Satisfaction Affects the Performance of the Education Personnel at the University of Muhammadiyah Jember

Ha6 : Competence Influences Performance Through Job Satisfaction of Educational Personnel, University of Muhammadiyah Jember

Ha7 : Perceived organizational support Influence Performance Through Job Satisfaction of Educational Personnel, University of Muhammadiyah Jember

\section{RESEARCH METHOD}

This research design is explanatory research that intends to explain the position of the variables studied and the influence between one variable and another (Sugiyono, 2017: 6). The population of this research is the educational staff of the Muhammadiyah University of Jember, totaling 120 people who are placed in libraries, laboratories, administrative bureaus, faculties, and technical units. Sampling in this study is a saturated sample, which is that all members of the population are selected to be the sample (Sugiyono, 2017: 85). The data analysis method used in this study was 
Partial Least Square (PLS) with SmartPLS software. This study uses the PLS method because it is in accordance with the research objectives to find a relationship between exploratory variables or theory expansion, does not seek a reciprocal relationship, and the sample used is relatively small. The PLS steps will be explained as follows (Ghozali, 2014: 37- 42):

1. Designing the Structural Model (inner model)

2. Designing the Measurement Model (outer model)

3. Path Diagram Construction

4. Converting the Path Diagram to a System of Equations
a. Outer Model
b. Inner Model (structural model equation)

5. Estimation: Weight, Path Coefficient, Loading

6. Evaluation of Goodness of Fit

a. The Outer Model consists of Convergent Validity, Discriminant Validity, Composite Reliability

b. Inner Model

c. Hypothesis Testing (resampling bootstrapping)

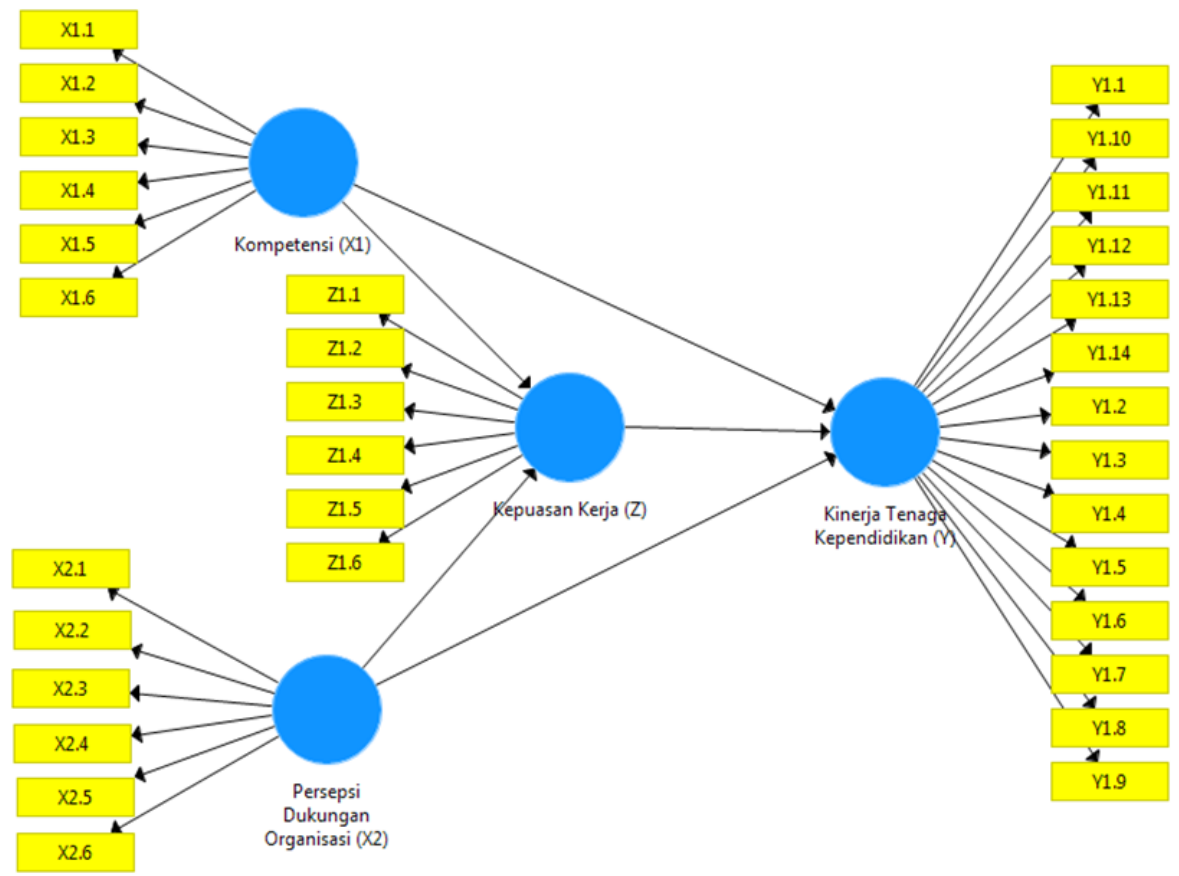

Figure 2. Conceptual Framework

\section{FINDINGS AND DISCUSSION}

Characteristics of Respondents

The characteristics of the prescription based on gender showed that $51.7 \%$ were male, and $48.3 \%$ were female. Characteristics of respondents based on age showed that those aged between 21-30 years were $53.3 \%$, aged between $31-40$ years were $24.2 \%$, aged between $41-50$ years were $10 \%$ and aged 51-60 were 12, 5\%. The characteristics of respondents according to work units indicate that as many as $33.3 \%$ are in administrative bureau work units, $34.2 \%$ are in faculty units, $6.7 \%$ are placed in libraries, $6.7 \%$ are in laboratories, and $19.2 \%$ are in at the technical implementation unit. 
The characteristics of respondents according to the latest education showed that $13.3 \%$ had a high school / vocational education, as much as $4.2 \%$ had a D1 / D2 / D3 education, as many as $80 \%$ had a Bachelor's degree (S1), and as many as 2, 5\% have a Master's degree (S2). Characteristics of respondents according to tenure showed that the work period of 1-10 years was $75 \%$, the work period was $11-20$ years as much as $9.2 \%$, the work period was $21-30$ years as much as $4.2 \%$, and as much as $11.7 \%$ with a working period of $31-40$ years.

Measurement Model Test (Outer Model)

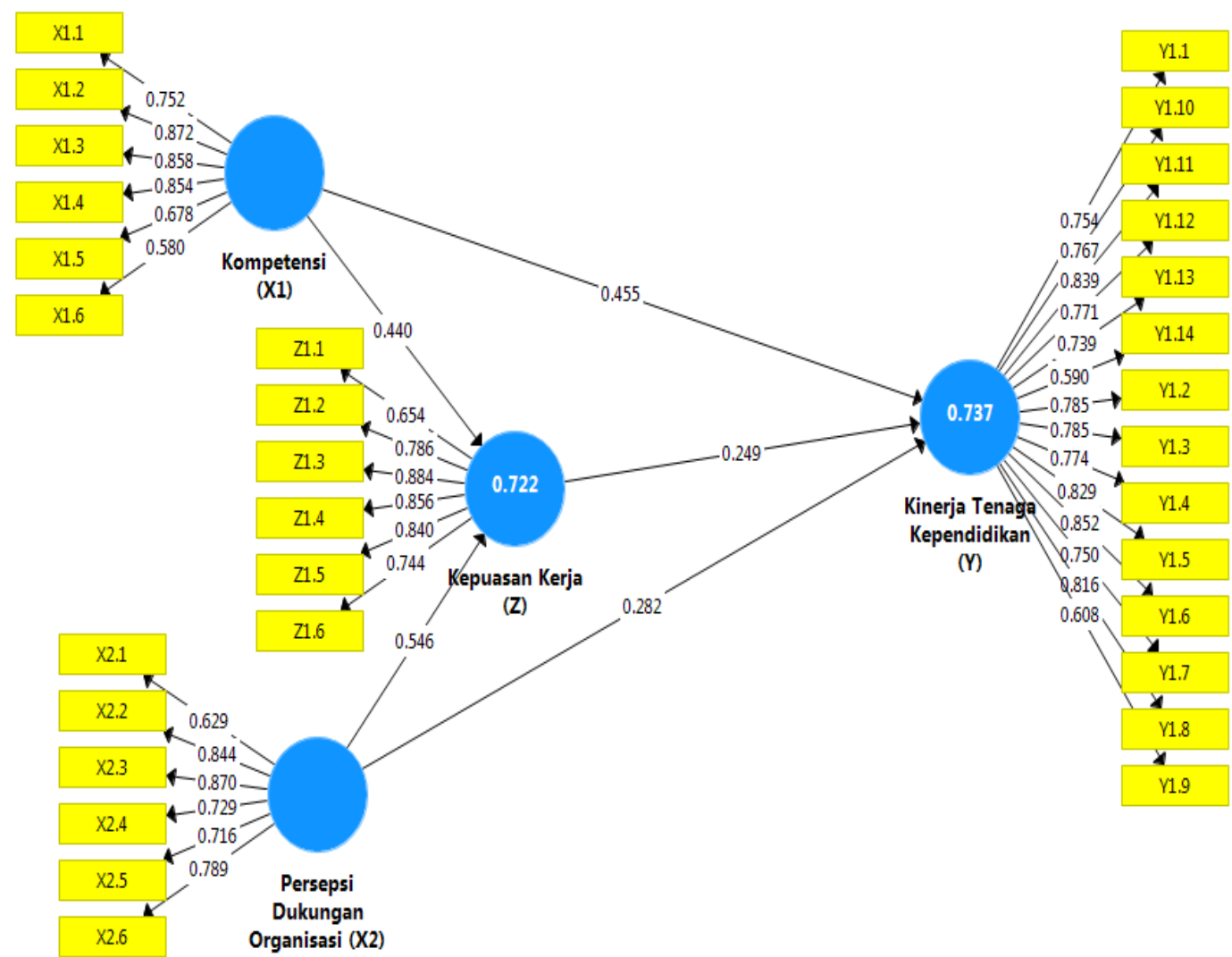

Figure 3 Measurement Model (Outer Model)

The convergent validity of the outer loading value in this study was declared valid or all feasible because no indicator had an outer loading value below 0.50 , so that further analysis could be carried out. Discriminate validity shows that the loading value of each indicator against the construct is greater than the cross-loading value, so in this case, it can be concluded that all latent variable constructs already have better discriminant validity than indicators in other blocks.

Table 1. Fornell-Larcker Criterion

\begin{tabular}{lcccc}
\hline & $\begin{array}{c}\text { Job } \\
\text { Satisfaction } \\
\text { (Z) }\end{array}$ & $\begin{array}{c}\text { Educational } \\
\text { Personnel } \\
\text { Performance (Y) }\end{array}$ & $\begin{array}{c}\text { Competenc } \\
\text { e (X1) }\end{array}$ & $\begin{array}{c}\text { Perceived } \\
\text { organizationa } \\
\text { 1 support (X2) }\end{array}$ \\
\hline Job Satisfaction (Z) & 0.798 & & & \\
\hline $\begin{array}{l}\text { Educational } \\
\begin{array}{l}\text { Personnel } \\
\text { Performance (Y) }\end{array}\end{array}$ & 0.781 & 0.765 & & \\
\hline
\end{tabular}


International Journal of Management, Entrepreneurship, Social Science and Humanities (IJMESH), Vol. 4 (2), 11-27 The Role of Job Satisfaction in Mediating the Effect of Competency and Perceived Organizational Support on Education Performance

Septy Holisa Umamy

\begin{tabular}{lcccc}
\hline Competence (X1) & 0.702 & 0.765 & 0.773 & \\
\hline $\begin{array}{l}\text { Perceived } \\
\text { organizational } \\
\text { support (X2) }\end{array}$ & 0.757 & 0.688 & 0.479 & 0.767 \\
\hline
\end{tabular}

Discriminant validity can be tested by comparing the AVE value with the correlation between other constructs in the model, if the root value of AVE $>0.50$, then the discriminant validity is achieved.

Table 2. AVE values

Average Variance Extracted (AVE)

\begin{tabular}{lc}
\hline Job Satisfaction (Z) & 0.637 \\
\hline Educational Personnel Performance (Y) & 0.585 \\
\hline Competence (X1) & 0.598 \\
\hline Perceived organizational support (X2) & 0.588 \\
\hline
\end{tabular}

The results of the AVE value of each variable are valid because all measurements are above 0.50 .

Composite reliability

Table 3. Composite Reliability and Cronbach's Alpha

\begin{tabular}{lrr}
\hline & Cronbach's Alpha & Composite Reliability \\
\hline Job Satisfaction (Z) & 0.883 & 0.912 \\
\hline $\begin{array}{l}\text { Educational Personnel } \\
\text { Performance (Y) }\end{array}$ & 0.944 & 0.951 \\
\hline Competence (X1) & 0.861 & 0.897 \\
\hline $\begin{array}{l}\text { Perceived organizational support } \\
\text { (X2) }\end{array}$ & 0.857 & 0.894
\end{tabular}

The results of measuring the composite reliability and Cronbach's alpha indicated that all variables for the composite reliability value had a value above 0.70 , while the Cronbach's alpha value had a value above 0.70 . These results indicate that if all variables are declared reliable or the variables in this study have become a fit measurement tool.

Structural Model Test (Inner Model)

Table 4. Value of R Square

\begin{tabular}{lcc}
\hline & R Square & \multicolumn{2}{c}{ R Square Adjusted } \\
\hline Job Satisfaction (Z) & 0.722 & 0.717 \\
\hline $\begin{array}{l}\text { Educational Personnel } \\
\text { Performance (Y) }\end{array}$ & 0.737 & 0.730
\end{tabular}

The result of the $\mathrm{R}$ Square value on the job satisfaction variable is 0.722 or $72.2 \%$ which is influenced by competence and perceived organizational support, while the remaining $27.8 \%$ is influenced by other variables so that the structural model formed is close to strong because the $\mathrm{R}$ Square value is close to 0.75 . The results of the $\mathrm{R}$ Square value on the educational staff performance variable are 0.737 or $73.7 \%$ which is influenced by competence, Perceived organizational support, and job satisfaction, while the remaining $26.3 \%$ is influenced by other variables in this case, the 
structural model formed is said to be close to strong because of the R-value. Square is approaching 0.75 .

The value of $Q$ Square predictive relevance can be measured by:

Q2 = 1- (1 - R Job Satisfaction 2) X (1 - R Education Personnel Performance 2)

$=1-(1-0,7222) \times(1-0,7372)$

$=1-(1-0,521) \times(1-0,543)$

$=1-(0.479) \times(0.457)$

$=1-0,218$

$=0.782$

The results of the $Q$ Square value in this study are 0.782 or $>0$ so that it can be said if the model has predictive relevance or shows that the structural model designed to explain job satisfaction and the performance of teaching staff at the University of Muhammadiyah Jember is proven to be good or relevant.

\section{Hypothesis testing}

Direct Effect Test

Table 5. Direct effects

\begin{tabular}{|c|c|c|c|c|c|c|}
\hline & $\begin{array}{l}\text { Original } \\
\text { Sample } \\
\text { (0) }\end{array}$ & $\begin{array}{l}\text { Sample } \\
\text { Mean } \\
\text { (M) }\end{array}$ & $\begin{array}{l}\text { Standard } \\
\text { Deviation } \\
\text { (STDEV) }\end{array}$ & $\begin{array}{l}\text { T Statistics } \\
(\mid 0 / \\
\text { STDEV |) }\end{array}$ & $\begin{array}{c}\mathrm{P} \\
\text { Values }\end{array}$ & $\begin{array}{c}\text { Informatio } \\
\mathrm{n}\end{array}$ \\
\hline $\begin{array}{l}\text { Competence (X1) -> } \\
\text { Educational Personnel } \\
\text { Performance (Y) }\end{array}$ & 0.455 & 0.451 & 0.071 & 6,432 & 0,000 & $\begin{array}{c}\text { Be } \\
\text { accepted }\end{array}$ \\
\hline $\begin{array}{l}\text { Perceived organizational } \\
\text { support (X2) -> } \\
\text { Educational Personnel } \\
\text { Performance (Y) }\end{array}$ & 0.282 & 0.276 & 0.087 & 3,259 & 0.001 & $\begin{array}{c}\text { Be } \\
\text { accepted }\end{array}$ \\
\hline $\begin{array}{l}\text { Competence (X1) -> Job } \\
\text { Satisfaction (Z) }\end{array}$ & 0.440 & 0.440 & 0.059 & 7.509 & 0,000 & $\begin{array}{c}\text { Be } \\
\text { accepted }\end{array}$ \\
\hline $\begin{array}{l}\text { Perceived organizational } \\
\text { support (X2) -> Job } \\
\text { Satisfaction (Z) }\end{array}$ & 0.546 & 0.546 & 0.054 & 10,076 & 0,000 & $\begin{array}{c}\text { Be } \\
\text { accepted }\end{array}$ \\
\hline $\begin{array}{l}\text { Job Satisfaction }(\mathrm{Z}) \text {-> } \\
\text { Educational Personnel } \\
\text { Performance (Y) }\end{array}$ & 0.249 & 0.258 & 0.096 & 2,580 & 0.010 & $\begin{array}{c}\text { Be } \\
\text { accepted }\end{array}$ \\
\hline
\end{tabular}

Hypothesis 1

The results of hypothesis testing show the t statistical value of $6.432>1.96$ and a P value of 0.000 $<0.05$ (accepted).

Hypothesis 2

The statistical $T$ value is $3.259>1.96$ and the $p$ value is $0.001<0.05$ (accepted). 
Hypothesis 3

The statistical $\mathrm{T}$ value is $7.509>1.96$ and the $\mathrm{p}$ value is $0.000<0.05$ (accepted).

Hypothesis 4

The statistical T value is $10.076>1.96$ and the $p$ value is $0.000<0.05$ (accepted).

Hypothesis 5

The statistical $\mathrm{T}$ value is $2.580>1.96$ and the $\mathrm{p}$ value is $0.010<0.05$ (accepted).

\section{Indirect Effect Test}

Table 6. Indirect Effects

\begin{tabular}{|c|c|c|c|c|c|c|}
\hline & $\begin{array}{l}\text { Original } \\
\text { Sample } \\
\text { (0) }\end{array}$ & $\begin{array}{l}\text { Sample } \\
\text { Mean } \\
\text { (M) }\end{array}$ & $\begin{array}{l}\text { Standard } \\
\text { Deviation } \\
\text { (STDEV) }\end{array}$ & $\begin{array}{l}\text { T Statistics } \\
(\mid \text { O / STDEV } \\
\text { |) }\end{array}$ & $\begin{array}{c}\mathrm{P} \\
\text { Values }\end{array}$ & Information \\
\hline $\begin{array}{l}\text { Competence (X1) -> } \\
\text { Job Satisfaction (Z) -> } \\
\text { Educational } \\
\text { Personnel } \\
\text { Performance (Y) }\end{array}$ & 0.110 & 0.115 & 0.048 & 2,263 & 0.024 & Be accepted \\
\hline $\begin{array}{l}\text { Perceived } \\
\text { organizational } \\
\text { support (X2) -> Job } \\
\text { Satisfaction (Z) -> } \\
\text { Educational } \\
\text { Personnel } \\
\text { Performance (Y) }\end{array}$ & 0.136 & 0.140 & 0.054 & 2,535 & 0.012 & Be accepted \\
\hline
\end{tabular}

Hypothesis 6

The statistical $\mathrm{T}$ value is $2.263>1.96$ and the $\mathrm{p}$ value is $0.024<0.05$ (accepted).

Hypothesis 7

The statistical T value is $2.535>1.96$ and the $p$ value is $0.012<0.05$ (accepted).

\section{Total Effect}

Table 7. Total Effect

\begin{tabular}{|c|c|c|c|c|}
\hline & & $\begin{array}{c}\text { Direct } \\
\text { Influence }\end{array}$ & Indirect Influence & Total Effect \\
\hline \multirow{2}{*}{$\begin{array}{lcc}\text { Competence } & (\mathrm{X} 1) \quad-> \\
\text { Educational } & \text { Personnel } \\
\text { Performance (Y) } & & \end{array}$} & T Statistics & 6,432 & 2,263 & 10,192 \\
\hline & P Value & 0,000 & 0.024 & 0,000 \\
\hline \multirow{3}{*}{$\begin{array}{l}\text { Perceived organizational } \\
\text { support (X2) -> Educational } \\
\text { Personnel Performance (Y) }\end{array}$} & T Statistics & 3,259 & 2,535 & 6,811 \\
\hline & P Value & 0.001 & 0.012 & 0,000 \\
\hline & T Statistics & 7.509 & & 7.509 \\
\hline
\end{tabular}


International Journal of Management, Entrepreneurship, Social Science and Humanities (IJMESH), Vol. 4 (2), 11-27

The Role of Job Satisfaction in Mediating the Effect of Competency and Perceived Organizational Support on Education Performance

Septy Holisa Umamy

\begin{tabular}{|c|c|c|c|}
\hline $\begin{array}{lll}\text { Competence (X1) } & -> & \text { Job } \\
\text { Satisfaction (Z) } & & \\
\end{array}$ & P Value & 0,000 & 0,000 \\
\hline \multirow{2}{*}{\begin{tabular}{lll} 
Perceived & \multicolumn{2}{c}{ organizational } \\
support $\quad(X 2) \quad->\quad$ Job
\end{tabular}} & T Statistics & 10,076 & 10,076 \\
\hline & P Value & 0,000 & 0,000 \\
\hline \multirow{2}{*}{$\begin{array}{l}\text { Job Satisfaction }(\mathrm{Z}) \quad-> \\
\text { Educational }\end{array}$} & T Statistics & 2,580 & 2,580 \\
\hline & P Value & 0.010 & 0.010 \\
\hline
\end{tabular}

Based on the results of the total effect presented in table 7. shows that job satisfaction has a mediating effect because the $t$ statistical value of the competency variable on the performance of education personnel through satisfaction has increased in the t statistic from 6.432 after mediation, job satisfaction increases to 10.192 meaning that job satisfaction provides full mediation. Job satisfaction also has a mediating effect on the variable Perceived organizational support on the performance of education personnel because the $t$ statistical results on the total effect have increased, initially the t statistical value was 3.259, but after mediation, job satisfaction increased to 6.811 , this proves that job satisfaction has a full mediating effect.

\section{DISCUSSION}

1. Competencies Influence the Performance of Educational Personnel at the University of Muhammadiyah Jember

The results of this hypothesis testing are accepted, which states that competence has an effect on the performance of the educational staff at the University of Muhammadiyah Jember. The University of Muhammadiyah Jember must conduct various training to support the competence of educational staff, both hard skills and soft skills. Competence for education personnel plays a role in making it easier to carry out work activities that have been determined by the University of Muhammadiyah Jember. The competencies possessed by educational staff are able to provide a stimulus or stimulation for performance so that performance will increase. This research is in line with the results of research conducted by Susanto (2018), Syarif (2020), Girniawan \& Perizade et al. (2019), Kurniawan, Martini and Herlambang (2020), Renyut, Modding et al. (2017).

2. Perceived organizational support Influence the Performance of Educational Personnel at the University of Muhammadiyah Jember

Perceived organizational support has an effect on the performance of the teaching staff at the Muhammadiyah University of Jember. Perceived organizational support is used to support the performance of teaching staff at the University of Muhammadiyah Jember; education staff perceives various things that are obtained from the organization. The Muhammadiyah University of Jember has provided welfare that supports work activities, including BPJS Health, BPJS Ketenagakerjaan, which consists of work accident insurance, old-age insurance, pension insurance, and death insurance. The University of Muhammadiyah Jember also gives awards for outstanding educational staff in the form of bonuses and rewards for educational staff whose work periods have reached 10 years and over in the form of Hajj and Umrah. But what needs to be improved again by the University of Muhammadiyah Jember is about the concern to listen to 
complaints and suggestions from education staff, especially about working hours, because if there is no follow-up from the leadership, it will cause a lack of attention from education personnel to the leadership. This study is in line with the results of research by Muizu et al (2019), Agustyna \& Prasetyo (2020), Cendekia \& Ningsih (2020), Murniasih \& Sudarma (2016).

3. Competencies Influence Job Satisfaction of Educational Personnel, University of Muhammadiyah Jember

Competency competence affects the job satisfaction of the teaching staff at the University of Muhammadiyah Jember. The competency possessed by the educational staff at the University of Muhammadiyah Jember is quite good because on the indicators of work that are in accordance with their personalities, there are already those who agree, but there are still educational staff whose main tasks and functions are not in accordance with their personality or educational background, besides that on the placement indicator education personnel in accordance with their expertise need to be considered because if this is neglected it will have an impact on the satisfaction or enthusiasm of education personnel to work. This research is in line with the research of Ramadhan, Pongtuluran and Wahyuni (2020), Fitri, Marnis and Garnasih (2020), Bha Dan Ye (2020), Firmansyah (2020).

4. Perceived organizational support Influence the Job Satisfaction of Educational Personnel, University of Muhammadiyah Jember

Perceived organizational support has an effect on accepted job satisfaction of educational personnel at the University of Muhammadiyah Jember. The amount of support provided by the University of Muhammadiyah Jember to education personnel will affect job satisfaction. This shows that if you want to get job satisfaction from education personnel, the University of Muhammadiyah Jember must focus on building Perceived organizational support by providing support both in terms of facilities, comfort in work, justice, and appreciation. The education staff's perception of the support of the Muhammadiyah University of Jember is good, but the perception of superiors' support is not good because there are several complaints from education staff that has not been heeded. The University of Muhammadiyah Jember is expected to provide a sense of empathy or give attention to education personnel, especially in support of superiors/leaders. This research has been conducted by Jang \& Juliana (2020), Sari (2019), Kristanti et al. (2019), which means that employees who perceive fair treatment from their organization and feel that they have support from their company will feel happy with their work, satisfied with promotions and rewards received from the company, and enjoy working with superiors and colleagues.

5. Job Satisfaction Affects the Performance of the Education Personnel at the University of Muhammadiyah Jember

The hypothesis that job satisfaction has an effect on the performance of the teaching staff at the University of Muhammadiyah Jember is accepted. Job satisfaction at the University of Muhammadiyah Jember is good, but the salary/reward indicator is still not good because there is a mismatch between workload and salary; besides that, there is some dissatisfaction in the placement of educational personnel so that it will affect their performance. Job satisfaction in 
career advancement is also not good because at the University of Muhammadiyah Jember, there is no mapping of educational personnel careers, and educational staff who occupy structural positions do not go through a promotion process but are appointed by the leadership to occupy vacant positions. Research conducted by Badrianto and Ekhsan (2020), Erniwati, Ramli, and Alam (2020), Rinny, Purba, and Handiman (2020) shows that there is a positive influence between job satisfaction on the performance of educational personnel.

6. Competence Influences Performance Through Job Satisfaction of Educational Personnel, University of Muhammadiyah Jember

The hypothesis of competence has an effect on performance through job satisfaction of the teaching staff at the University of Muhammadiyah Jember is accepted. Empirically, to improve the performance of the teaching staff of the Muhammadiyah University of Jember, it is better to pay attention to competency factors that will increase job satisfaction. The competence of education personnel at the University of Muhammadiyah Jember is good, including skills in operating software (computers, office applications, etc.) and technical skills in the use of onlinebased service information systems at the University of Muhammadiyah Jember. However, the University of Muhammadiyah Jember must provide training to increase competence. Job satisfaction in education personnel is good, However, in the provision of salaries/incentives, it is necessary to re-evaluate because there must be a match between workload and salary, and the placement indicator according to expertise must be considered.

This is supported by the results of research conducted by Hidayat, et al (2020), Prasyanto (2017), Saragih et al. (2017), showing that job satisfaction has a positive and significant effect in mediating competence on performance. And the placement indicators according to expertise must be considered. The performance of education personnel is already good, especially in indicators of being able to carry out the duties and functions of the applicable soup and capable of serving the improvement of data/applications of the academic community in accordance with procedures and regulations. These results indicate that to improve performance, it is necessary to increase the competence of the personnel so that it will create a sense of job satisfaction.

7. Perceived organizational support Influence Performance Through Job Satisfaction of Educational Personnel, University of Muhammadiyah Jember

The hypothesis of perceived organizational support affects performance through job satisfaction of the Muhammadiyah University of Jember education personnel is accepted. Testing this hypothesis shows that the perception of education personnel towards the University of Muhammadiyah Jember is already good, especially in providing welfare and security at work by providing BPJS guarantees for both BPJS health and BPJS Ketenagakerjaan and giving rewards to educational personnel whose work periods are 10 years and above, but in Organizational support at the University of Muhammadiyah Jember needs to pay attention to indicators of superior concern/empathy for complaints from education personnel, especially in determining working hours. The job satisfaction felt by education staff is good, but the salary indicator needs to be re-evaluated, the indicators of superiors who are able to provide technical assistance and motivation need to be improved. The performance of the educational staff is 
good, especially in the indicators in carrying out the duties of the educational staff, always prioritizing the interests of the University of Muhammadiyah Jember rather than personal interests and education personnel play an active role in the activities of the University and Muhammadiyah organizations, but there are still some things that need to be evaluated, especially in the discipline of doing presence SIMPEG and Fingerprint still have educational staff who do not have an awareness of presence, and on the indicators of their rights and obligations during working hours there is still education personnel who arrive late and leave early. This proves that if the University of Muhammadiyah Jember wants to improve the performance of education personnel, it is necessary to pay attention to Perceived organizational support so that it will create a sense of satisfaction at work. Previous research was also conducted by Imam \& Javed (2019), Mursidta (2017) that there is a positive and significant influence on perceived organizational support on performance mediated by job satisfaction.

\section{CONCLUSION}

The novelty of research before this performance research was carried out, there were previous researchers who had found factors that support performance, but this study focuses on the performance of education personnel in which individual behavior (competence, perception, and satisfaction) towards work behavior using the PLS method. This study contributes that institutions must pay attention to individual behavior that will have an impact on the performance behavior of educational personnel.

Competence has a significant effect on the performance of the teaching staff at the University of Muhammadiyah Jember; this proves that the higher the competence of the teaching staff, the higher the performance. This research is supported by research by Susanto (2018), Syarif (2020), which states that competence affects performance.

Perceived organizational support has a significant effect on the performance of the teaching staff at the University of Muhammadiyah Jember; this shows that the better the Perceived organizational support, the better the performance of the teaching staff. This study is in accordance with the results of research by Muizu et al. (2019), Agustyna \& Prasetyo (2020) that the perception of organizational support has an effect on performance.

Competence has a significant effect on the job satisfaction of teaching staff at the University of Muhammadiyah Jember; this proves that the higher the competence of the teaching staff, the greater the sense of satisfaction in work. This research is supported by the research results of Ramadhan, Pongtuluran, and Wahyuni (2020), Fitri, Marnis, and Garnasih (2020), which state that competence affects job satisfaction.

Perceived organizational support has a significant effect on the job satisfaction of teaching staff at the University of Muhammadiyah Jember; this shows that the better the perception of educational staff towards the University of Muhammadiyah Jember will lead to a sense of satisfaction at work. This study is in accordance with the research of Jang \& Juliana (2020), Sari (2019) that the perception of organizational support has an effect on job satisfaction. 
Job satisfaction has a significant effect on the performance of the teaching staff of the Muhammadiyah University of Jember; this shows that the better job satisfaction, the better the performance. Research supports the research results of Badrianto and Ekhsan (2020), Erniwati, Ramli, and Alam (2020) that job satisfaction affects performance.

Competence has a significant effect on performance through job satisfaction of the teaching staff of the Muhammadiyah University of Jember; this shows that the higher the competence of the educational staff, the higher the job satisfaction so that it can produce the best performance. This study is in accordance with the results of research conducted by Hidayat et al. (2020), Prasyanto (2017), which states that competence has an effect on performance mediated by job satisfaction.

Perceptions of support have a significant effect on performance through job satisfaction of the teaching staff at the University of Muhammadiyah Jember; this proves that the better the perceptions of teaching staff towards the University of Muhammadiyah Jember, it will increase job satisfaction which will have an impact on improving performance. This research is supported by the results of research by Imam \& Javed (2019), which states that perceptions of organizational support have an effect on performance mediated by job satisfaction.

\section{Limitation \& Further Research}

The limitations of this research are that when filling out the questionnaire, the respondents do not directly fill in, there are still some answers from respondents who are inconsistent, the focus of the object of this research is only education personnel so that the results of this study cannot be generalized to employees at Muhaamdiyah University Jember because they have not included educators as objects of the research.

Future research can add other variables that affect performance, change the research location and research object. Suggestions from this research are expected that the University of Muhammadiyah Jember will map the education staff, increase the Perceived organizational support, especially superiors' support, make workload adjustments with salaries, and make career plans for educational personnel.

\section{REFERENCES}

Afandi P. (2018). Human Resource Management (Theory, Concepts and Indicators). Riau: Zanafa Publishing.

Agustiningrum S D. (2016). The Influence of Perceived organizational support on Employee Performance Mediated by OCB (Organizational Citizenship Behavior) (Study at PT Angkasa Pura I Surabaya Branch Office). Journal of Management Science. 4 (2). 212-225.

Agustyna A, Prasetio A P. (2020). The Influence of Perceived organizational support and Job Satisfaction on Employee Performance at PT Great Citra Lestari. Journal of Management Partners. 4 (1). 28-38.

Aima H, Adam R, Ali H. (2017). Model of Employee Performance: Competence Analysis and Motivation (Case Study at PT. Bank Bukopin, Tbk Center). Quest Journals Journal of Research in Business and Management. 4 (11) .49-59.http://www.questjournals.org/ 
Badrianto Y, Ekhsan M. (2020). Effect Of Work Environment And Job Satisfaction On Employee Performance In PT. Nesinak Industries. Journal of Business, Management, and Accounting. 2 (1). 85-91.http://e-journal.stie-kusumanegara.ac.id

Bha UAT, Ye Y. (2020). The Relationship Between Teachers' Competence And Their Job Satisfaction At Phaung Daw Oo Monastic Education High School, In Mandalay Division, Myanmar. Scholar Human Sciences 12 (1). 103-115.

DE scholar, Ningsih LS R. (2020). The Influence of Perceived organizational support and Work Motivation on Work Productivity of Bale Tani Jombang Tourism Employees. BIMA: Journal of Business and Innovation Management. 3 (1) .98-112.

Erniwati, Ramly M, Alam R. (2020). Leadership style, organizational culture and job satisfaction at employee performance. Point of View Research Management. 1 (3) .0918.https://journal.accountingpointofview.id/index.php/povrema

Firmasyah F, Brahmasari IA, Ratih IA B. (2020). The Effect of Individual Characteristics, Competence on Job Satisfaction and Employee Performance of IKM Batik in Pamekasan. International Journal of Innovative Science and Research Technology. 5 (4) .12301239.www.ijisrt.com

Fitri R, Marnis, Garnasih R L. (2020). Influence Of Competence And Training On Job Satisfaction And Its Impact On The Performance Of Employees Of The Investment And One Stop Integrated Services Office Of Riau Province. Procuratio: Scientific Journal of Management. 8 (3). 291307.

Ghozali I. (2014). Structural Equation Modeling, Alternative Method with Partial Least Square (PLS). Edition 4. Semarang: Diponegoro University Publishing Agency.

Girniawan E, Perizade B, Bemby B, Robiani B. (2019). The Influence of Leadership, Organizational Culture, and Competence on Employee Performance of the Ministry of Agrarian Affairs and Spatial Planning / BPN Palembang City Land Office. Sriwijaya Journal of Management and Business. 17 (1).

Hidayat A, Mattalatta S, Sani A, NM N. (2020). The Effect of Competence on Performance through Job Satisfaction at the Makassar City Social Service. Journal of Mirai Management. 6 (1). 202212.

https://journal.stieamkop.ac.id/index.php/mirai/article/view/715/422

Imam S, Javed T. (2019). Job Security, Organizational Support and Employee Performance: Mediating role of Employee Satisfaction in Medical Sector of Pakistan. International Journal Academic Research Business and Social Sciences. 9 (3). 12501268.http://dx.doi.org/10.6007/IJARBSS/v9-i3/5793

Ivancevich JM, Konopaske R, Matteson, M T. (2005). Organizational Behavior and Management Seven Edition. New Yor: McGraw-Hill Companies. Translation by Gina Gania. (2007). Organizational Behavior and Management. Seventh Edition. Jakarta. Erlangga Publisher.

Jang J, Juliana. (2020). The Influence of Perceived organizational support and Job Satisfaction on Work Commitment and Organizational Citizenship Behavior of Millennial Generation in the Education Industry. JIMEA | MEA Scientific Journal (Management, Economics, and Accounting). 4 (1). 141-160.

Kristanti FT, Prasetio AP, Putri NNS, Nadhirah S. (2019). Affective Commitment to BPR 'ABC' Employees in Garut; Analysis of the Direct Effect of Perceived organizational support and the 
International Journal of Management, Entrepreneurship, Social Science and Humanities (IJMESH), Vol. 4 (2), 11-27 The Role of Job Satisfaction in Mediating the Effect of Competency and Perceived Organizational Support on Education Performance

Septy Holisa Umamy

Role of Mediating Job Satisfaction. ISEI Business and Management Review. 3 (1). 7 15.http://jurnal.iseibandung.or.id/index.php/ibmr

Kurniawan AR, Martini NYP, Herlambang T. (2020). The Influence of Transformational Leadership, Job Competence and Work Motivation on Employee Performance at Bank Jatim, Situbondo. Indonesian Journal of Management and Business. 6 (1).

Marhayani, Musnadi S, Ibrahim M. (2019). Effect Of Competence And Employee Commitment To Employee Performance: Job Satisfaction As A Mediator (Study On Watering Office Of Aceh Province). International Journal of Business Management and Economic Review. 2 (1). 1527.http://ijbmer.org/

Muizu WOZ, Putri NA, Soemaryani I. (2019). The Influence Of Organizational Support Perception On The Performance Of Regional Development Organizations In Bandung City With The Top Support As A Moderated Variable. Journal of Economics and Applied Business. 15 (2). 108116.http://journal.feb.unpad.ac.id/index.php/jebt

Murniasih E, Sudarma K. (2016). The Effect of Perceived organizational support and Competence on Employee Performance Mediated by Affective Commitment. Management Analysis Journal. 5 (1). 24-35.

Mursidta S. (2017). The Influence of Perceived Organizational Support and Job Satisfaction on Employee Performance at PT. Varia of Gresik Concrete Business. Journal of Management Science (JIM). 5 (1). 1-12.

https://jurnalmahasiswa.unesa.ac.id/index.php/jim/article/view/18387/16763

Prasyanto G. R. (2017). The Influence of Employee Competence on Performance with Job Satisfaction as an Intervening Variable (Study at PT. Dok and Shipping Surabaya, Production Section). Journal of Management Science (JIM). 5 (2). 18.https://ejournal.unesa.ac.id/index.php/jim/article/view/18887

Ramadhan R, Pongtuluran Y, Wahyuni S. (2020). Analysis of the influence of leadership and discipline and competence on employee job satisfaction and organizational commitment. Management Journal. 12 (2). 306- 316.

Renyut BC, Modding HB, Sukmawati S. (2017). The effect of organizational commitment, competence on Job satisfaction and employees performance in Maluku Governor's Office. IOSR Journal of Business and Management (IOSR-JBM). 19 (11). 18-29.

Rinny P, Purba CB, Handiman U T. (2020). The Influence Of Compensation, Job Promotion, And Job Satisfaction On Employee Performance Of Mercubuana University. International Journal of Business Marketing and Management (IJBMM). 5 (2). 39-48.http://www.ijbmm.com/

Saragih B, Sanusi A, Manan A. (2017). The Influence of Job Satisfaction towards Employee Performance on the Antecedent of Competencies and Organizational Citizenship Behavior. IOSR Journal of Business and Management (IOSR-JBM). 19 (1). 21-27. http://www.iosrjournals.org/iosr-jbm/papers/Vol19-issue1/Version-7/D1901072127.pdf

Sari N K. (2019). The Influence of Perceived organizational support and Organizational Justice on Job Satisfaction (For Employees of PT. Dwiwira Lestari Jaya, Biatan District, Berau Regency, East Kalimantan Province). Psikoborneo: Scientific Journal of Psychology. 7 (1). 123-134.

Sinambela L P. (2016). Human Resource Management. Jakarta. PT Bumi Aksara.

Sugiyono. (2017). Quantitative Research Methods, Qualitative, and R \& D. Bandung: Alfabeta. 
Susanto A. (2018). The Influence of Work Environment and Individual Competence on Employee Performance at PT. North Sumatra Plantation. Journal of Management and Business (JMB). 18 (1). 44-59.http://ejournal.ust.ac.id/index.php/JIMB_ekonomi

Syarif A. (2020). Analysis of the Influence of Leadership, Organizational Culture and Competence on Employee Performance of PHM CPU Production Team. Indonesian Journal of Management and Business. 6 (1). 12-18.

Tagala M. (2018). Industrial and Organizational Psychology. Depok: Publisher PT RajaGrafindo Persada.

Tewal B, Adolfina, Pandowo M, Tawas H N. (2017). Organizational behavior. Bandung. Publisher CV. Patra Media Grafindo.

Umrani WA, Afsar B, Khan M, Ahmed U. (2019). Addressing The Issue Of Job Performance Among Hospital Physicians In Pakistan: The Role Of Job Security, Organizational Support, And Job Satisfaction. Journal of Applied Bobehavioral Research.https://doi.org/10.1111/jabr.12169

Warsi DAS, Siswanta L, Wahyuni ET, Sukhemi. (2020). Analysis of the Effect of Leadership Style, Job Satisfaction on the Performance of Bisman Education Personnel (Business and Management): The Journal Of Business and Management. 3 (1). 1-12.

Wijaya C. (2017). Organizational behavior. Medan: Indonesian Education Development Concerned Institution.

Yulivianto T S. (2019). Job Crafting and Perceived organizational support for Employee Performance Through Work Engagement. Journal of Management Science. 7 (4). 1017-1028. 